\title{
Comparison of development of pig zygotes and embryos in simple and complex culture media
}

\author{
J. W. Pollard ${ }^{1}$, C. Plante ${ }^{2 *}$ and S. P. Leibo ${ }^{\mathrm{I}}$ \\ Departments of ${ }^{1}$ Biomedical Sciences and ${ }^{2}$ Population Medicine, Ontario Veterinary College, University of \\ Guelph, Guelph, Ontario, Canada N1G 2W1
}

\begin{abstract}
The development of pig zygotes and embryos in three culture media was investigated. Zygotes and morulae, recovered from superovulated prepubertal gilts after slaughter, were randomly allocated to culture in one of three simple media: (i) Chatot, Ziomek, Bavister medium (CZB) in 5\% $\mathrm{CO}_{2}: 95 \%$ air; (ii) Hepes-buffered CZB medium (H-CZB) in $100 \%$ air; or in a complex solution enriched with vitamins and amino acids; or (iii) modified Eagle's minimal essential medium (Pig-MEM) in $5 \% \mathrm{CO}_{2}: 95 \%$ air. The relative effectiveness of the various media and gas combinations was assessed by determining the percentage of zygotes and morulae that developed into blastocysts and hatched from their zonae, as well as by the mean number of cells per embryo. Of zygotes cultured either in $\mathrm{CZB}$ in $\mathrm{CO}_{2}$ :air, or in $\mathrm{H}-\mathrm{CZB}$ in air alone, $65 \%$ and $57 \%$ developed into blastocysts, respectively; no zygotes cultured in Pig-MEM in $\mathrm{CO}_{2}$ :air developed beyond the four-cell stage. After $115 \mathrm{~h}$ of culture, embryos resulting from zygotes cultured in either CZB or H-CZB contained approximately 50 cells per embryo. Morulae differed from zygotes in their developmental potential in the three media in that virtually all morulae cultured in $\mathrm{CZB}, \mathrm{H}-\mathrm{CZB}$ or Pig-MEM developed to the expanded blastocyst stage in vitro. However, of blastocysts resulting from morulae cultured in Pig-MEM, 97\% hatched from their zonae, whereas only $8 \%$ and $5 \%$, respectively, of those resulting from morulae cultured in CZB or $\mathrm{H}-\mathrm{CZB}$ did so. Furthermore, those blastocysts that developed from morulae in Pig-MEM contained significantly more cells than did embryos cultured in either CZB or H-CZB. More than $60 \%$ of 80 zygotes cultured in simple media without glucose developed into expanded blastocysts, but $<30 \%$ hatched. In contrast, $\geq 70 \%$ of 40 zygotes first cultured in CZB or $\mathrm{H}-\mathrm{CZB}$ to the morula stage and then placed into Pig-MEM hatched from their zonae. After being held briefly in $\mathrm{H}-\mathrm{CZB}, 42 \%$ of 91 embryos transferred into four of five recipients that became pregnant developed into fetuses or live young.
\end{abstract}

\section{Introduction}

Substantial progress has been made in devising in vitro culture conditions for pig zygotes and cleavage stage embryos. As described in two recent reviews (Reed et al., 1992; Petters and Wells, 1993), three types of culture condition have been studied: (i) organ culture, in which the embryos are grown within oviducts either in vivo or in vitro; (ii) co-culture with somatic cells, with oviductal cells, or in media supplemented with oviductal fluid; (iii) culture in defined media. Early pig embryos develop into morulae or blastocysts with varying degrees of success in all three systems. Only organ culture or co-culture systems appear to support the development into blastocysts of zygotes and embryos earlier than the four-cell stage (Archibong et al., 1989; Krisher et al., 1989a; White et al., 1989; Prather et al., 1991). Nevertheless, because simple, defined culture media are easiest to replicate, and because the

*Correspondence.

Revised manuscript received 22 September 1994. influence of the addition or elimination of individual components can be studied easily in simple solutions, considerable attention has been paid to devising such media.

The relationship between various energy sources and metabolism of pig embryos has been examined in some detail (reviewed in Petters and Wells, 1993). The utilization of glucose by pig embryos exhibits a very significant increase at the compacted morula stage (Flood and Wiebold, 1988), suggesting that their energy requirements change at that stage. Pig embryos at various initial stages have been successfully cultured in vitro to the blastocyst stage in both simple and complex salt solutions, including Eagle's minimal essential medium (MEM) and Kreb's-Ringer bicarbonate medium (KRB), a derivative of a medium of Brinster, both supplemented with different sources of energy (Stone et al., 1984; Rosenkrans et al., 1989; Meyen et al., 1989; Petters et al., 1990).

Pig zygotes can also develop at high rates into blastocysts in media without glucose (Hagen et al., 1991; Misener et al., 1991). Using CZB medium devised by Chatot et al. (1989) specifically for the culture of mouse zygotes, Misener et al. 
(1991) briefly reported that the same high percentage of $>90 \%$ of pig zygotes developed into morulae or blastocysts in the presence or absence of glucose. Comparing several modifications of Tyrode's media and TCM199, Hagen et al. (1991) found that the same percentages of $50-60 \%$ of one- and two-cell embryos developed into morulae or blastocysts in modified Tyrode's medium with either glucose or glutamine or with neither energy source. Their modifications of Tyrode's solution were the marked reduction of the bicarbonate concentration, the addition of Hepes as a buffer, and the culture of the embryos in air with no increase in $\mathrm{CO}_{2}$ content of the gaseous atmosphere. The influence of glucose in the media on the development of pig zygotes was shown to depend also on the $\mathrm{NaCl}$ concentration and osmolality of either modified Whitten's medium or mKRB, both of which contain glucose, pyruvate and lactate (Beckmann and Day, 1993). The addition of hyaluronic acid to Whitten's medium containing BSA aiso improves the development of one- and two-cell embryos into blastocysts (Miyano et al., 1994).

Development of pig blastocysts ceases in vitro after blastocyst expansion if embryos are maintained in simple medium similar to those used for the successful culture of pig zygotes (Rosenkrans et al., 1989). Continued development and hatching of cultured pig blastocysts appear to require the presence of serum and amino acid supplements in the culture media (Robl and Davis, 1981; Niemann et al., 1983; Stone et al., 1984; Meyen et al., 1989; Rosenkrans et al., 1989). Adding growth factors or oviductal fluid alone to a basal culture medium (NCSU 23) is reported to be of limited value for in vitro development of pig embryos (Eberhardt et al., 1994), but addition of fatty acid-free BSA does enhance development.

The objective of the present study was to compare the efficacy of three culture media in supporting development of pig zygotes into expanded and hatched blastocysts. The aim was to identify media that would permit embryos to be handled in air alone (no increase in $\mathrm{CO}_{2}$ ) without damage, and could also be used for in vitro culture to assess embryo viability. The media tested were $C Z B$, as first described by Chatot et al. (1989), and Eagle's MEM, as modified by Malayer et al. (1988), both of which require high $\mathrm{CO}_{2}$ to maintain a neutral $\mathrm{pH}$. In addition, a Hepes-buffered modification of $\mathrm{CZB}$ medium (H-CZB) was tested, because it would eliminate the necessity of an increase in $\mathrm{CO}_{2}$ content in the atmosphere for the routine recovery, handling, culture and transfer of pig embryos. $\mathrm{CZB}$ medium was found to be effective for culturing mouse zygotes, particularly from strains early embryos of which exhibited the so-called 'two-cell block' (Chatot et al., 1990), bovine embryos (Ellington ef al., 1990), and pig embryos, in a preliminary study (Misener et al., 1991). Modified Eagle's MEM was selected because of its common use for maintaining hatched pig blastocysts (Basha et al., 1980). In addition, a 'mixed media' experiment was conducted, in which zygotes cultured in $\mathrm{CZB}$ or $\mathrm{H}-\mathrm{CZB}$ to the morula stage were also cultured in MEM for an additional $72 \mathrm{~h}$.

\section{Materials and Methods}

Chemicals were obtained from Sigma Chemical Company (St Louis, MO) and media from GIBCO (Grand Island Biologi-
Table 1. Media compositions

\begin{tabular}{|c|c|c|}
\hline \multirow[b]{2}{*}{ Component } & \multicolumn{2}{|c|}{ Media (mmol l-1) } \\
\hline & $\mathrm{CZB}^{*}$ & $\mathrm{H}-\mathrm{CZB}$ \\
\hline $\mathrm{NaCl}$ & 81.62 & 81.62 \\
\hline $\mathrm{KCl}$ & 4.83 & 4.83 \\
\hline $\mathrm{CaCl}_{2} \cdot 2 \mathrm{H}_{2} \mathrm{O}$ & 1.70 & 1.70 \\
\hline $\mathrm{KH}_{2} \mathrm{PO}_{4}$ & 1.18 & 1.18 \\
\hline $\mathrm{MgSO}_{4} \cdot 7 \mathrm{H}_{2} \mathrm{O}$ & 1.18 & 1.18 \\
\hline $\mathrm{NaHCO}_{3}$ & 25.12 & 4.00 \\
\hline Hepes & - & 20.00 \\
\hline Sodium pyruvate & 0.27 & 0.27 \\
\hline Sodium lactate & 31.30 & 31.30 \\
\hline Glutamine & 1.00 & 1.00 \\
\hline EDTA & 0.11 & 0.11 \\
\hline $\mathrm{BSA}\left(\mathrm{Fr} \mathrm{V} ; \mathrm{g} \mathrm{I}^{-1}\right)$ & 5.00 & 5.00 \\
\hline Sodium penicillin $\mathrm{G}\left(\mathrm{U} \mathrm{ml}^{-1}\right)$ & 100.00 & 100.00 \\
\hline Streptomycin $\left(\mathrm{mg} \mathrm{ml}^{-1}\right)$ & 0.70 & 0.70 \\
\hline Phenol red $\left(\mathrm{mg} \mathrm{ml}^{-1}\right)$ & - & 0.01 \\
\hline $\mathrm{pH}$ & 7.4 & 7.4 \\
\hline Osmolality (mosmol) & 275 & 270 \\
\hline
\end{tabular}

*As described by Chatot et al. (1989).

cal Company, Grand Island, NY), unless otherwise stated. Embryo recovery and manipulation procedures were conducted at a temperature of $35^{\circ}-38^{\circ} \mathrm{C}$ using warmed media and temperature-controlled warming plates, pads and water baths. Embryo age was defined in terms of time after donor gilts were injected with human chorionic gonadotrophin (hCG; Ayerst, Quebec) designated as time $=0$.

\section{Embryo culture media}

The CZB medium was prepared as described by Chatot $e t$ al. (1989) (Table 1). The modification, called H-CZB, consisted of adding Hepes to $\mathrm{CZB}$ medium, decreasing the concentration of $\mathrm{NaHCO}_{3}$, and adding phenol red. Where indicated, $\mathrm{CZB}$ and $\mathrm{H}-\mathrm{CZB}$ were supplemented with $20 \%(\mathrm{v} / \mathrm{v})$ heat-treated fetal calf serum (FCS; Hyclone Inc., Logan, UT). Modified Eagle's minimal essential medium (Pig-MEM) was prepared as described by Malayer et al. (1988) and contained $4 \mathrm{~g}$ glucose $1^{-1}, 2 \times$ non-essential MEM-amino acids, $2 \times$ MEM-vitamins, $8.2 \mathrm{mg}$ insulin $\mathrm{I}^{-1}$ and $20 \%(\mathrm{v} / \mathrm{v})$ FCS. All media were prepared with water from a Millipore Reverse Osmosis System (Model Milli-RO 15) and a Millipore Filtration System (Model Milli-Q

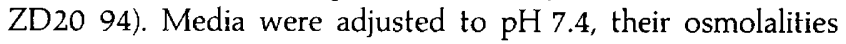
measured and adjusted to about $270 \mathrm{mOsm}$ when necessary, and filter-sterilized through $0.22 \mu \mathrm{m}$ Millipore filters. The first $10 \mathrm{ml}$ of media passing through each filter was discarded. Media found to differ by more than 3\% from the desired osmolality were discarded.

\section{Embryo recovery and handling}

All animals were handled and experiments were conducted according to guidelines of the Canadian Council of Animal Care. Follicular maturation and ovulation were induced in 
prepubertal Large White gilts by i.m. injection of $1000 \mathrm{iu}$ equine chorionic gonadotrophin (eCG; Ayerst, Quebec) and 500 iu hCG was injected $72 \mathrm{~h}$ later. Donor gilts, which were 5-6 months old, of mass $105-115 \mathrm{~kg}$, were artificially inseminated $36 \mathrm{~h}$ after hCG injection with semen collected from Large White boars immediately before insemination. Zygotes and morulae were recovered from donor gilts that were killed at 52 and $120 \mathrm{~h}$ after hCG injection, respectively. At slaughter, the animals were used by several groups of investigators for different purposes. For those animals whose ovaries were available for detailed counting, the mean ovulation rate was 24.5; an average of 20.9 embryos per gilt were collected. All embryos were recovered and handled at $35^{\circ}-38^{\circ} \mathrm{C}$ in $\mathrm{H}$-CZB. Only embryos with spermatozoa visible on their zona pellucida and of excellent morphology, as described by Krisher et al. (1989b), Hagen et al. (1991) and Petters et al. (1990), were used for culture. Care was taken to maintain reproductive tracts, uterine flushings and recovered embryos above $35^{\circ} \mathrm{C}$ from the time of slaughter of the donors to embryo culture.

\section{Embryo culture}

Within $30 \mathrm{~min}$ of their collection, zygotes or morulae recovered from individual donor gilts were randomly allocated to culture in the three culture media. Thus, depending on the number of embryos collected from each gilt, embryos from one gilt were cultured in two or three media, and embryos from two or more gilts were cultured in the same media. Groups of four to five embryos were cultured in $100 \mu \mathrm{l}$ droplets of media held under $1 \mathrm{ml}$ of silicone oil (Medical Fluid 200; $50 \mathrm{cSt}$ viscosity; Dow Corning Corp., Midland, MI) in four-well tissue culture plates (Nunc, GIBCO-BRL, NY). After culture plates containing embryos in droplets of either CZB or Pig-MEM were placed into a modular culture chamber (BillipsRothenberg, Del Mar, CA), the chamber itself was purged with pre-warmed and humidified $5 \% \mathrm{CO}_{2}$ in air. Other culture plates containing embryos in $\mathrm{H}-\mathrm{CZB}$ droplets were transferred into a similar culture chamber filled only with air. Both culture chambers were sealed and placed into a $39^{\circ} \mathrm{C}$ water-jacketed incubator. High humidity within individual chambers was achieved by placing an open Petri dish of $150 \mathrm{~mm}$ diameter filled with Milli-Q water in the bottom of each chamber. Every $48 \mathrm{~h}$, droplets of culture media were replaced with fresh media. The development of the embryos was assessed at intervals of $24 \mathrm{~h}$, with embryos classified as either 1-, 2-, 4-, 6- to 8-, $>8$-cell, compact morulae, early blastocyst, blastocyst, expanded blastocyst, hatching blastocyst or hatched blastocyst. The number of cells comprising individual embryos in the various treatment groups was determined at about 72, 96, 120, 144 and $168 \mathrm{~h}$ for cultured zygotes, and at 120,144 and $168 \mathrm{~h}$ for cultured morulae. Groups of ten embryos were randomly selected from each culture treatment at the indicated times, and were fixed in methanol:acetic acid (3:1), spread on glass slides, and stained for counting (King et al., 1979). To estimate the rate of the cell division of the embryos, the logs of the mean celi numbers of each group were plotted as a function of time, as described by Dawes (1969).

\section{Experimental design}

In the first experiment, the development of zygotes in CZB, H-CZB or Pig-MEM was determined. In the second experiment, the development of morulae in the same media was measured. In the third experiment, zygotes first cultured in $\mathrm{CZB}$ or $\mathrm{H}-\mathrm{CZB}$ until they developed into morulae were then cultured in $C Z B$ alone, $C Z B+F C S, H-C Z B$ alone, $\mathrm{H}-\mathrm{CZB}+\mathrm{FCS}$, or Pig-MEM. As a preliminary test of the effects of handling embryos in $\mathrm{H}-\mathrm{CZB}$, some two-cell and four-cell embryos that had been held for $>4 \mathrm{~h}$ in $\mathrm{H}-\mathrm{CZB}$ in air alone at $38^{\circ} \mathrm{C}$ were surgically transferred into the uteri of synchronized recipients.

\section{Statistical analyses}

Regression analysis or analysis of variance was performed on continuous (logarithm of cell numbers) and categorical responses (embryos developing to the blastocyst and hatched blastocyst stage) by the least-squares analysis of variance using the General Linear Models procedures of the Statistical Analysis System (SAS Institute Inc., 1988a). Categorical data were transformed by the empirical logit $(Y=\log [($ Observed +0.5$) /$ (Total number-Observed +0.5)]; Cox and Snell, 1987). Homogeneity of variance was tested on residuals using the Univariate procedure (SAS, 1988b). Particular attention was placed on the degree of kurtosis (shape of the curve), skewness (tailing of the curve) and the probability associated with distribution testing of normality ( $W$ normality test) of the residuals (Zar, 1974).

\section{Results}

When zygotes were cultured in the three test media, approximately two-thirds of groups of 50 zygotes each in CZB and $\mathrm{H}-\mathrm{CZB}$ developed into blastocysts; none of the 46 zygotes in Pig-MEM developed. Very few of the blastocysts actually hatched from their zonae (Table 2). The log of the number of cells of embryos cultured in CZB and H-CZB increased with time up to about $168 \mathrm{~h}$ after hCG treatment (Fig. 1). The mean number of cells of a total of ten embryos per medium cultured in the two media reached about 50 cells per embryo after about $120 \mathrm{~h}$ in culture. Those zygotes cultured in Pig-MEM did not develop beyond an average of 3-4 cells per embryo. Analysis of both the categorical (Table 2) and the continuous responses (Fig. 1) demonstrated that both the percentage of blastocysts, and the number of cells per embryo of those that developed in $\mathrm{CZB}$ or in $\mathrm{H}-\mathrm{CZB}$ were statistically greater than those that developed in Pig-MEM.

In contrast, when embryos recovered from gilts as morulae were placed into the three media, virtuaily all of about 40 embryos per medium developed into blastocysts, and there was no statistical difference between the three media (Table 3). However, although only a few of the blastocysts that developed in CZB or H-CZB hatched from their zonae, $97 \%$ of 41 blastocysts that developed in Pig-MEM did so; the hatching 
Table 2. Development of pig zygotes in $C Z B, H-C Z B$ and Pig-MEM media

\begin{tabular}{lcccc}
\hline $\begin{array}{l}\text { Culture } \\
\text { medium }\end{array}$ & $\begin{array}{c}\text { Number of } \\
\text { zygotes } \\
\text { cultured }\end{array}$ & $\begin{array}{c}\text { Number of } \\
\text { replicates }\end{array}$ & $\begin{array}{c}\text { Number of } \\
\text { blastocysts } \\
(168 \mathrm{~h})(\%)\end{array}$ & $\begin{array}{c}\text { Number of } \\
\text { hatched blastocysts } \\
(192 \mathrm{~h})(\%)\end{array}$ \\
\hline CZB & 50 & 5 & $38(65)^{\mathrm{a}}$ & $2(4)^{\mathrm{a}}$ \\
H-CZB & 50 & 5 & $33(57)^{\mathrm{a}}$ & $1(2)^{\mathrm{a}}$ \\
Pig-MEM & 46 & 5 & $0(0)^{\mathrm{b}}$ & $0(0)^{\mathrm{a}}$ \\
\hline
\end{tabular}

Source

Degree of significance (blastocysts)

Treatment (orthogonal contrasts)
$\mathrm{CZB}$ versus $\mathrm{H}-\mathrm{CZB}$
0.158
$\mathrm{CZB}$ and $\mathrm{H}-\mathrm{CZB}$ versus $\mathrm{Pig}-\mathrm{MEM}$
$2 \times 10^{-9}$

Values with different superscript letters in the same column are significantly different $(P<0.05)$ based on Ryan-Einot-Gabriel-Welsch multiple range test.

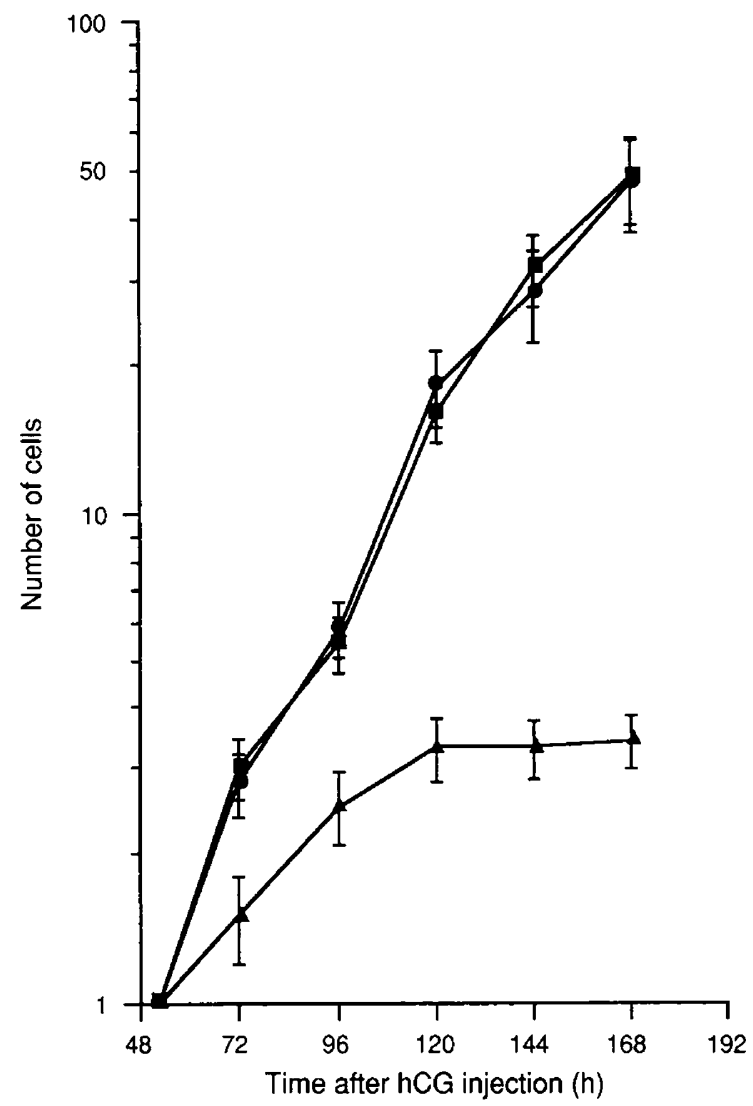

Fig. 1. Mean number of cells of pig embryos $(n=10$ per time per

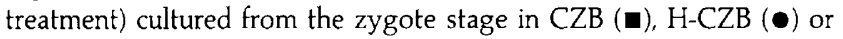
Pig-MEM ( $\mathbf{\Lambda})$ medium.

percentages were statistically different (Table 3). Furthermore, the logs of the mean numbers of cells of embryos in the three media increased with time, although the rates of cell division in CZB and H-CZB were considerably lower than in Pig-MEM (Fig. 2). The numbers of cells per embryo that developed in
Table 3. Development of pig embryos whose culture was begun at the morula-stage in CZB, H-CZB or Pig-MEM media

\begin{tabular}{lcccc}
\hline $\begin{array}{l}\text { Culture } \\
\text { medium }\end{array}$ & $\begin{array}{c}\text { Number of } \\
\text { morulae } \\
\text { cultured }\end{array}$ & $\begin{array}{c}\text { Number of } \\
\text { replicates }\end{array}$ & $\begin{array}{c}\text { Number of } \\
\text { blastocysts after } \\
168 \mathrm{~h}(\%)\end{array}$ & $\begin{array}{c}\text { Number of } \\
\text { hatched } \\
\text { blastocysts after } \\
192 \mathrm{~h}(\%)\end{array}$ \\
\hline CZB & 38 & 6 & $37(97)^{\mathrm{a}}$ & $3(8)^{\mathrm{a}}$ \\
H-CZB & 40 & 6 & $40(100)^{\mathrm{a}}$ & $2(2)^{\mathrm{a}}$ \\
Pig-MEM & 41 & 6 & $41(100)^{\mathrm{a}}$ & $40(97)^{\mathrm{b}}$
\end{tabular}

Degree of significance

(Hatched

Source

(Blastocysts*) blastocysts)

Treatment (orthogonal contrasts)

CZB versus $\mathrm{H}-\mathrm{CZB}$

0.499

$\mathrm{CZB}$ and $\mathrm{H}-\mathrm{CZB}$ versus Pig-MEM

0.501

$5 \times 10^{-8}$

Values with different superscript letters in the same column are significantly different $(P<0.05)$ based on Ryan-Einot-Gabriel-Welsch multiple range test. *Transformed by the empirical logit $\{y=\log [($ Observed +1$) /($ Total number - Observed +1 )] .

$\mathrm{CZB}$ and $\mathrm{H}-\mathrm{CZB}$ were significantly lower than in embryos that developed in Pig-MEM (Table 4).

To determine whether morulae that were derived by in vitro culture of zygotes were developmentally equivalent to those morulae collected at that stage, a 'mixed media' experiment was conducted. Two sets of controls consisted of zygotes cultured in CZB or in $\mathrm{H}-\mathrm{CZB}$ continuously. As shown in Table 5 , of those cultured in $\mathrm{CZB}, 80 \%$ and $62 \%$ developed into morulae and blastocysts, respectively; of those in $\mathrm{H}-\mathrm{CZB}$, the corresponding percentages were $75 \%$ and $55 \%$. The addition of FCS to CZB medium did not alter the percentage of zygotes that developed into blastocysts, but it did significantly increase the percentage of those blastocysts that hatched. When morulae that developed from zygotes in CZB were transferred into Pig-MEM medium, not only did a significantly greater percentage develop into blastocysts, but more importantly $75 \%$ of the blastocysts hatched from their zonae. Analogous results were obtained for zygotes cultured first in H-CZB and then transferred into either H-CZB + FCS or into Pig-MEM: that is, the hatching rate of blastocysts was enhanced by the addition of FCS to the culture medium. In addition, a significantly greater percentage of blastocysts hatched when morulae that developed from zygotes in H-CZB were transferred into Pig-MEM for the final $72 \mathrm{~h}$ of culture.

As a preliminary test of $\mathrm{H}-\mathrm{CZB}$ as a holding medium, 113 embryos coilected at the two- or four-cell stage and incubated in air alone for $>4 \mathrm{~h}$ in $\mathrm{H}-\mathrm{CZB}$ at $38^{\circ} \mathrm{C}$ were transferred into five gilts, four of which became pregnant. When two of the pregnant recipients, into which 21 and 25 embryos had been transferred, were slaughtered on day 35 of gestation, they contained 9 and 12 normally developed fetuses, respectively. The other two pregnant recipients, into which 25 and 20 embryos had been transferred, were allowed to farrow, resulting in the birth of four and 13 live piglets. In total, $33.6 \%$ of 113 transferred embryos developed into normal fetuses and 


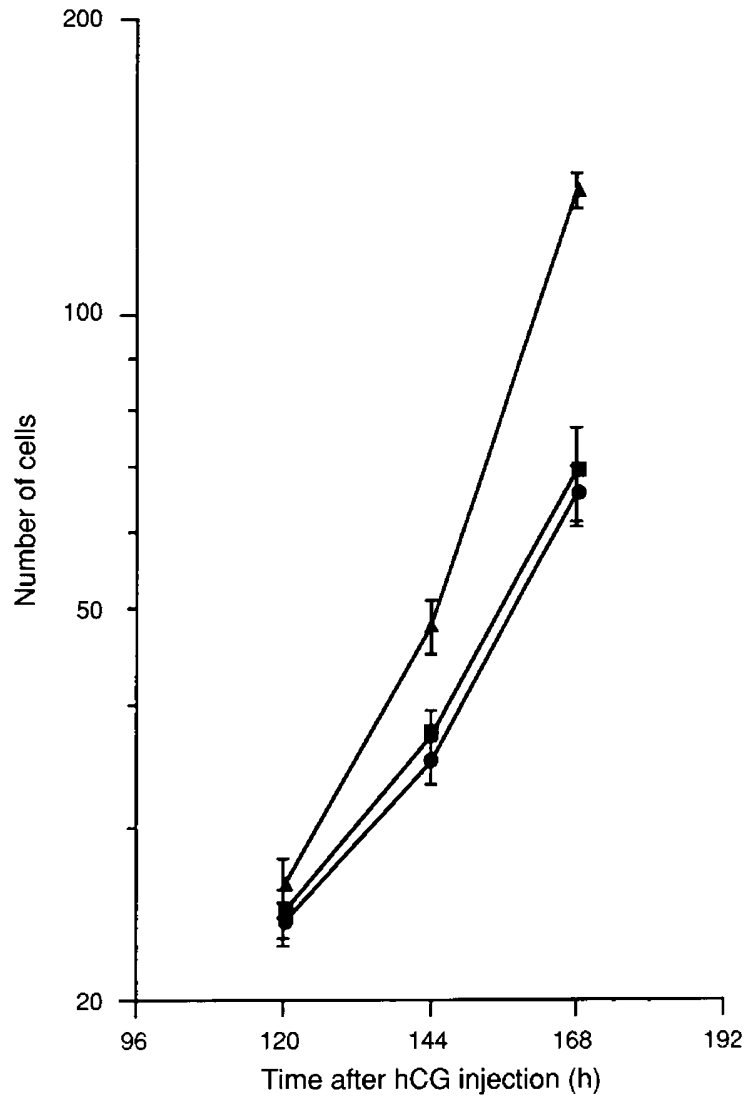

Fig. 2. Mean number of cells of pig embryos cultured from the

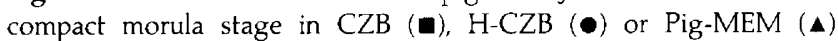
medium.

live young, representing $41.8 \%$ of the embryos transferred into the four recipients that became pregnant.

\section{Discussion}

The in vitro development of pig embryos has been shown to depend upon the stage of the embryo at the initiation of culture and the composition of the culture medium (for reviews see Reed et al., 1992; Petters and Wells 1993). In the study reported here, zygotes developed into blastocysts in either CZB or $\mathrm{H}-\mathrm{CZB}$ medium, but did not develop in Pig-MEM. These results confirm the findings of other investigators who have demonstrated that simple culture media can support the development of pig zygotes to the blastocyst stage (Wright, 1977; Menino and Wright, 1982; Petters et al., 1990; Hagen et al., 1991; Beckmann and Day, 1993), but that complex media cause development of zygotes to become arrested at or before the four-cell stage (Hagen et al., 1991). The development of blastocysts in $\mathrm{H}-\mathrm{CZB}$ also confirms the earlier report by Hagen et al. (1991), who found that the zwitterion, Hepes, is a suitable replacement for the $\mathrm{NaHCO}_{3}-\mathrm{CO}_{2}$ buffer system. However, the equivalent efficacy of $\mathrm{CZB}$ and $\mathrm{H}-\mathrm{CZB}$ to support zygote development to the blastocyst stage contrasts with the results of Hagen et al. (1991), who found that the $\mathrm{NaHCO}_{3}-\mathrm{CO}_{2}-$ buffered Tyrode's medium did not support development.
Table 4. Analysis of variance of cell numbers at 120, 144 and $168 \mathrm{~h}$ of embryos placed into culture as morulae in $\mathrm{CZB}$, $\mathrm{H}-\mathrm{CZB}$ or Pig-MEM media

\begin{tabular}{lc}
\hline Source & $\begin{array}{c}\text { Degree of significance } \\
\text { (number of cells) }\end{array}$ \\
\hline $120 \mathrm{~h}$ & \\
Treatment & 0.565 \\
Contrast & \\
CZB versus H-CZB & 0.778 \\
CZB and H-CZB versus Pig-MEM & 0.307 \\
$144 \mathrm{~h}$ & \\
Treatment & 0.002 \\
Contrast & \\
CZB versus H-CZB & 0.509 \\
CZB and H-CZB versus Pig-MEM & 0.0005 \\
168 h & \\
Treatment & $1 \times 10^{-8}$ \\
Contrast & \\
CZB versus H-CZB & 0.671 \\
CZB and H-CZB versus Pig-MEM & $2 \times 10^{-9}$ \\
\hline
\end{tabular}

The rates of development of zygotes into blastocysts in either $\mathrm{CZB}$ or $\mathrm{H}-\mathrm{CZB}$ medium are comparable to those obtained in modified Krebs-Ringer bicarbonate medium (Petters et al., 1990), modified Whitten's medium (Beckmann and Day, 1993), or Hepes-buffered Tyrode's medium (Hagen et al., 1991).

The actual development rates of zygotes, derived from the plot of log [cell numbers per embryol versus time, in CZB and $\mathrm{H}-\mathrm{CZB}$ were virtually identical. The respective totals of 48 and 47 cells in embryos derived from zygotes cultured in CZB or $\mathrm{H}-\mathrm{CZB}$ are comparable to those obtained in studies of porcine embryos cultured in a bicarbonate medium ( 58 cells: Krisher et al., 1989a; 29 cells: Petters et al., 1990), in Whitten's medium (52 cells: Youngs et al., 1993), and are similar to those of embryos maintained in organ culture (59-72 cells: Krisher $e$ t al, 1989a; 48 cells: Krisher et al., 1989b). The hatching percentage of embryos cultured continuously from the zygote to the blastocyst stage in $\mathrm{CZB}$ or $\mathrm{H}-\mathrm{CZB}$ was very low. A comparison of the rates of development of embryos, collected as morulae, as a function of time in CZB, H-CZB or Pig-MEM was also made. The mean number of cells in embryos developing from morulae was greater than that in embryos developing from zygotes; nevertheless, the development rates as a function of time were similar. Further evidence that these media support normal development was provided by comparison with observations of Papaioannou and Ebert (1988). In their study, although the total numbers of cells of embryos from 31 gilts vary substantially, the logs of the mean number of cells recovered on days 5-8 after the onset of oestrus increased with time. These data provide an excellent estimate of the rate of development of pig embryos in vivo. Comparison of the data from the present study for in vitro development of pig embryos with those of Papaioannou and Ebert for in vivo development suggests that the time-dependent rates are similar (Fig. 3). 
Table 5. Development of embryos collected as zygotes and cultured in one medium for $84 \mathrm{~h}$, and then transferred into a second medium at the morula stage for an additional $72 \mathrm{~h}$

\begin{tabular}{|c|c|c|c|c|c|}
\hline \multicolumn{2}{|c|}{$\begin{array}{c}\text { Culture Media } \\
\text { Zygote } \rightarrow \text { Morulae }\end{array}$} & \multirow{2}{*}{$\begin{array}{c}\text { Number of } \\
\text { zygotes } \\
\text { cultured }\end{array}$} & \multirow{2}{*}{$\begin{array}{c}\text { Number of } \\
\text { morulae } \\
(120 \mathrm{~h})(\%)\end{array}$} & \multirow{2}{*}{$\begin{array}{l}\text { Number of } \\
\text { blastocysts } \\
(168 \text { h) (\%) }\end{array}$} & \multirow{2}{*}{$\begin{array}{l}\text { Number of } \\
\text { hatched } \\
\text { blastocysts } \\
\text { (192 h) (\%) }\end{array}$} \\
\hline 1st medium & 2nd medium & & & & \\
\hline \multirow{3}{*}{$\mathrm{CZB} \rightarrow$} & $\mathrm{CZB}$ & 20 & $18(80)$ & $13(62)^{\mathrm{abc}}$ & $1(5)^{\mathrm{bc}}$ \\
\hline & $\mathrm{CZB}+\mathrm{FCS}$ & 20 & $16(80)$ & $14(69)^{\mathrm{abc}}$ & $6(30)^{\mathrm{b}}$ \\
\hline & Pig-MEM & 20 & $18(88)$ & $18(88)^{\mathrm{a}}$ & $15(75)^{\mathrm{a}}$ \\
\hline \multirow{3}{*}{$\mathrm{H}-\mathrm{CZB} \rightarrow$} & $\mathrm{H}-\mathrm{CZB}$ & 20 & $15(75)$ & $11(55)^{\mathrm{c}}$ & $0(0)^{c}$ \\
\hline & $\mathrm{H}-\mathrm{CZB}+\mathrm{FCS}$ & 20 & $16(80)$ & $12(60)^{b c}$ & $5(25)^{b}$ \\
\hline & Pig-MEM & 20 & $17(85)$ & $17(85)^{\mathrm{ab}}$ & $14(70)^{\mathrm{a}}$ \\
\hline
\end{tabular}

Source

(Blastocysts)

Degree of significance

\begin{tabular}{llc}
\hline Treatment (orthogonal contrasts) & & \\
$\mathrm{C} Z \mathrm{~B} \rightarrow \mathrm{CZB}$ versus $\mathrm{CZB} \rightarrow \mathrm{CZB}+\mathrm{FCS}$ & 0.883 & 0.021 \\
$\mathrm{CZB} \rightarrow \mathrm{CZB}+\mathrm{FCS}$ versus CZB $\rightarrow$ Pig-MEM & 0.019 & $4 \times 10^{-5}$ \\
$\mathrm{H}-\mathrm{CZB} \rightarrow \mathrm{H}-\mathrm{CZB}$ versus H-CZB $\rightarrow \mathrm{H}-\mathrm{CZB}+\mathrm{FCS}$ & 0.719 & 0.008 \\
$\mathrm{H}-\mathrm{CZB} \rightarrow \mathrm{H}-\mathrm{CZB}+\mathrm{FCS}$ versus H-CZB $\rightarrow$ Pig-MEM & 0.002 & $2 \times 10^{-5}$ \\
$\mathrm{CZB}$ (1st medium) versus H-CZB (1st medium) & 0.343 & 0.508 \\
\hline
\end{tabular}

Times refer to hours after hCG injection of donors.

Values with different letters in the same column are significantly different $(P<0.05)$ based on Ryan-Einot-Gabriel-Welsch multiple range test.

${ }^{\dagger}$ Transformed by the empirical logit $\{y=\log [($ Observed +1$) /($ Total number - Observed +1$)]\}$.

The development of morulae (placed into culture immediately after collection from donors) differed significantly from those derived from the culture of zygotes. A high percentage of in vivo morulae developed to the expanded blastocyst stage in all of the tested media, whereas only about twothirds of in vitro morulae developed in $\mathrm{CZB}$ and $\mathrm{H}-\mathrm{CZB}$, and none developed in Pig-MEM medium. The number of cells comprising blastocysts that developed in the different media also differed. Those morulae cultured in the complex medium Pig-MEM had a significantly higher mean number of cells than did those developing in either of the simpler media. Although high percentages of morulae developed into blastocysts in CZB or in $\mathrm{H}-\mathrm{CZB}$, very few hatched. In contrast, almost all of the blastocysts derived from morulae cultured in Pig-MEM hatched from their zonae. However, addition of fetal calf serum to both CZB and H-CZB did significantly increase the number of blastocysts that hatched in vitro, compared with that observed in serum-free medium. This beneficial effect of a biological macromolecule for the culture of pig embryos is similar to that found for pig oviductal fluid (Archibong et al., 1989), or for addition of serum to the medium (Robl and Davis, 1981; Stone et al., 1984; Rosenkrans et al., 1989). The high rates of blastocyst development and zona hatching observed in the present study appear to differ from the observations of Meyen et al. (1989), who suggest that embryos of different genotypes may respond differently in culture. In the study reported here, $99 \%$ of a total of 119 morulae obtained from the mating of Large White gilts to Large White boars developed into blastocysts in the three media, and $97 \%$ of 41 morulae cultured in Pig-MEM hatched from their zonae.

Although many of the cultured embryos formed blastocysts and even hatched from their zonae, the percentage of the zygotes that developed completely in vitro was significantly less than that reported for development in vivo (Pope and Day, 1972; Hunter, 1974; Davis, 1985). Such a reduction in development rate has been observed during culture in vitro (Davis, 1985; Papaioannou and Ebert, 1988; Rosenkrans et al., 1989). The point at which embryonic development ceased in the study reported here depended upon the media and the embryo stage at the start of culture. None of the embryos, even those that hatched in vitro, elongated, and all slowly degenerated at about $240 \mathrm{~h}$ after hCG.

Identification of media suitable for handling and culture of pig zygotes and compact morulae either in air or in a $\mathrm{CO}_{2}$-supplemented environment was achieved in the present study. The identification of methods for handling embryos without impairing their developmental capability is important for deriving and testing new techniques for domestic livestock species. This is particularly true for procedures such as cryopreservation for which rapid bioassays of cell viability after various treatments are essential.

The authors thank K. Anderka, N. Songsasen, N. Rumph, and E. St John for their expert technical assistance in the completion of these studies. They also thank V. E. Papaioannou for providing the actual data for number of cells of collected embryos, as described in Papaioannou and Ebert (1988). This research was supported by 


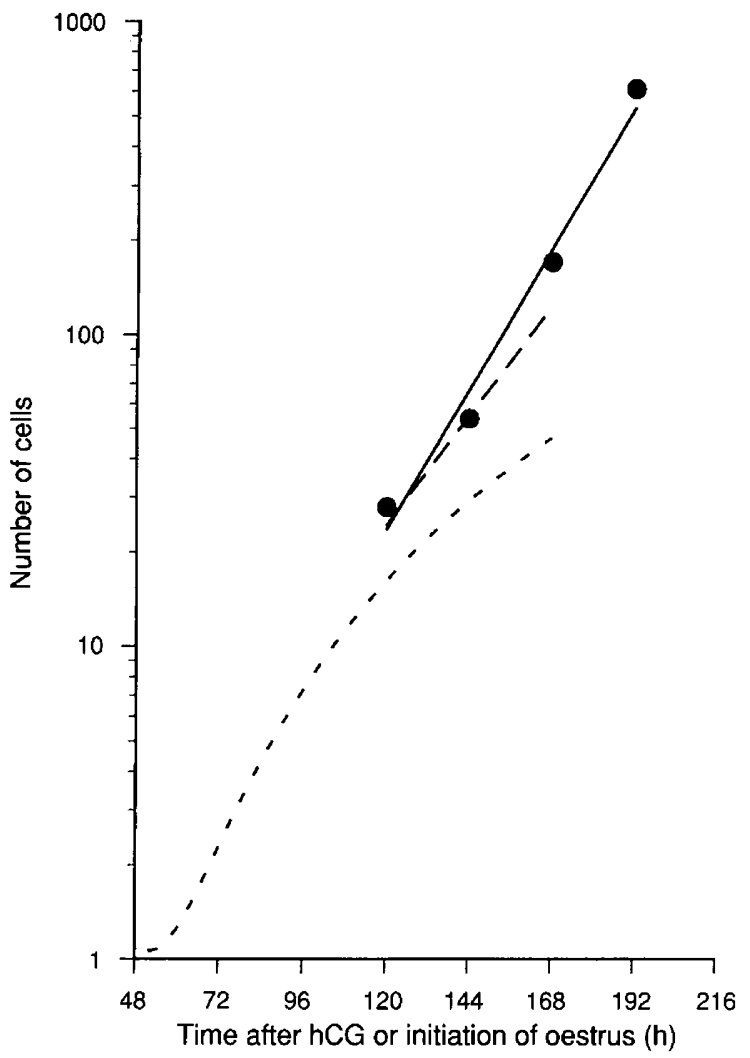

Fig. 3. Comparison of the log of the mean number of cells of pig embryos that developed in vitro in either H-CZB (- - ) or Pig-MEM $(---)$ with the log of the mean number of embryos collected directly from pigs (- data from Papaioannou and Ebert, 1988).

NSERC grant OGPO124429 and the Ontario Ministry of Agriculture and Food.

\section{References}

Archibong AE, Petters RM and Johnson BH (1989) Development of porcine embryos from one- and two-cell stages to blastocysts in culture medium supplemented with porcine oviductal fluid Biology of Reproduction 41 1076-1083

Basha SMM, Bazer FW and Roberts RM (1980) Effect of the conceptus on quantitative and qualitative aspects of uterine secretion in pigs Journal of Reproduction and Fertility $6041-48$

Beckmann LS and Day BN (1993) Effects of media $\mathrm{NaCl}$ concentration and osmolarity on the culture of early-stage porcine embryos and the viability of embryos cultured in a selected superior medium Theriogenology 39 611-622

Chatot CL, Ziomek CA, Bavister BD, Lewis JL and Torres I (1989) An improved culture medium supports development of random-bred 1-cell mouse embryos in vitro Journal of Reproduction and Fertility 86 679-688

Chatot CL, Lewis JL, Torres I and Ziomek CA (1990) Development of 1-cell embryos from different strains of mice in CZB medium Biology of Reproduction $42432-440$

Cox DR and Snell EJ (1987) Analysis of Binary Data pp 31-32 Eds Chapman and Hall. Thomson Press, New York

Davis DL (1985) Culture and storage of pig eggs Journal of Reproduction and Ferility Supplement 33 115-124

Dawes ES (1969) Quantitative Problems in Biochemistry (4th Edn), Williams and Wilkins Co, Baltimore

Eberhardt DM, Henricks DM, Dickey JF and Diehl JR (1994) Oviductal fluid and growth factors failed to enhance development of porcine embryos Theriogenology 41 1163-1172

Ellington JE, Carney EW, Farrell PB, Simkin ME and Foote RH (1990) Bovine 1-2-cell embryo development using a simple medium in three oviduct epithelial cell coculture systems Biology of Reproduction 43 97-104
Flood MR and Wiebold JL (1988) Glucose metabolism by preimplantation pig embryos Journal of Reproduction and Fertility 84 7-12

Hagen DR, Prather RS, Sims MM and First NL (1991) Development of one-cell porcine embryos to the blastocyst stage in simple media Journal of Animal Science 69 1147-1150

Hunter RHF (1974) Chronological and cytological details of fertilization and early embryonic development in the domestic pig, Sus scrofa Anatomical Record 178 169-186

King WA, Linares T, Gustavsson I and Bane A (1979) A method for preparation of chromosomes from bovine zygotes and blastocysts Veterinary Science Communications 3 51-56

Krisher RL, Petters RM and Johnson BH (1989a) Effect of oviductal condition on the development of one-cell porcine embryos in mouse or rat oviducts maintained in organ culture Theriogenology 32 885-892

Krisher RL, Petters RM, Johnson BH, Bavister BD and Archibong AE (1989b) Development of porcine embryos from the one-cell stage to blastocyst in mouse oviducts maintained in organ culture Journal of Experimental Zoology 249 235-239

Malayer JR, Hansen PJ and Buhi WC (1988) Secretion of proteins by cultured bovine oviducts collected from estrus through early diestrus Journal of Experimental Zoology 248 345-353

Menino AR, Jr and Wright RW, Jr (1982) Development of one-cell porcine embryos in two culture systems Journal of Animal Science 54 583-588

Meyen BA, Rosenkrans CF, Jr and Davis DL (1989) Development of pig blastocysts in vitro is altered by serum, bovine serum albumin and amino acids Theriogenology 31 463-471

Misener M, Pollard JW and Metzger K (1991) In vitro culture of porcine embryos in CZB medium Theriogenology 35244 (Abstract)

Miyano T, Hiro-oka RE, Kano K, Miyake M, Kusunoki H and Kato S (1994) Effects of hyaluronic acid on the development of 1- and 2-cell porcine embryos to the blastocyst stage in vitro Theriogenology 41 1299-1305

Niemann H, Illera MJ and Dziuk PJ (1983) Developmental capacity, size and number of nuclei in pig embryos cultured in vifro Animal Reproduction Science 5 311-321

Papaioannou VE and Ebert KM (1988) The preimplantation pig embryo: cell number and allocation to trophectoderm and inner cell mass of the blastocyst in vivo and in vitro Development 102 793-803

Petters RM and Wells KD (1993) Culture of pig embryos Journal of Reproduction and Fertility Supplement 48 6I-73

Petters RM, Johnson BH, Reed ML and Archibong AE (1990) Glucose, glutamine and inorganic phosphate in early development of the pig embryo in vitro Journal of Reproduction and Fertility $89269-275$

Pope CE and Day BN (1972) Development of pig embryos following restriction to the ampulla portion of the oviduct Journal of Reproduction and Fertility 31 135-138

Prather RS, Sims MM and First NL (1991) Culture of porcine embryos from the one- and two-cell stage to the blastocyst stage in sheep oviducts Theriogenology 35 1147-1151

Reed ML, Illera MJ and Petters RM (1992) In vitro culture of pig embryos Theriogenology 37 95-109

Robl JM and Davis DL (1981) Effects of serum on swine morulae and blastocysts in vitro Journal of Animal Science $\mathbf{5 2}$ 1450-1456

Rosenkrans CF Jr, Davis DL and Milliken G (1989) Pig blastocyst development in vitro is affected by amino acids Journal of Animal Science 67 1503-1508

SAS Institute Inc (1988a) SAS Procedures Guide Release 6.03 Ed p 44I. SAS Institute Inc, Cary, NC

SAS Institute Inc (1988b) SAS/STAT User's Guide Release 6.03 Ed p 1028. SAS Institute Inc, Cary, NC

Stone BA, Quinn P and Seamark RF (1984) Energy and protein sources for development of pig embryos cultured beyond hatching in vitro Animal Reproduction Science 7 405-412

White KL, Hehnke K, Rickords LF, Southern LL, Thompson DL and Wood TC (1989) Early embryonic development in vitro by coculture with oviductal epithelial cells in pigs Biology of Reproduction $41425-430$

Wright RW (1977) Successful culture in vitro of swine embryos to the blastocyst stage Journal of Animal Science 44 854-858

Youngs CR, Ford SP, McGinnis LK and Anderson LH (1993) Investigations into the control of litter size in swine. I. Comparative studies on in vitro development of Meishan and Yorkshire preimplantation embryos Journal of Animal Science 71 1561-1565

Zar JH (1974) The normal distribution. In Biostatistical Analysis pp 70-85 Eds WD McElroy and CP Swanson. Prentice-Hall, Inc, Englewood Cliffs, $\mathrm{NJ}$ 